\author{
Dragan Gavrilović \\ Marija Stamenković \\ ${ }^{1}$ University of Priština, \\ Faculty of Technical Sciences \\ ${ }^{2}$ University of Priština, \\ Faculty of Technical Sciences \\ 'gavrilovicd@ni.ac.rs \\ ${ }^{2}$ marijastamenkovic81@gmail.com
}

\section{ECOLOGICAL BENEFITS OF GREENING BUILDING ENVELOPES}

Abstract: Extensive urban development brings many adverse impacts which are reflected in degradation of quality of life and health of residents. Some of these impacts are related to increasing impermeable surfaces in city centers, made of concrete, asphalt, glass, etc. From environmental point of view, negative effects of urbanization include increased temperature and the effect of urban heat island which affects global warming, air pollution, flood risks and reduction of space for plants and animals. One of the ways to mitigate these effects is greening building envelope.

This paper deals with ecological benefits which can be achieved by covering the building surfaces with greenery. Comparative analyses of buildings covered with greenery and with conventional materials were done based on data from certain studies conducted abroad. The results shown in the paper indicate a significant improvement in the living conditions in green covered buildings, and confirm that integration of vegetation represents a sustainable approach for the envelope of new and existing buildings.

Key words: green roofs, green facades, urban environment, ecological benefits, sustainable design.

\section{INTRODUCTION}

Planting and preservation of greenery in urban areas is an essential component in sustainable urban development. As densely built urban areas are primarily covered with water-impermeable surfaces, green spaces are formed within the city parks and along streets. Due to lack of space the only way to increase greenery is to plant it on buildings over green roofs and green facades. These systems do not require additional space because they are already part of the building footprint.

It is widely known that greening the building envelope is not a new approach. It dates back to the traditional architecture, 2000 years ago. Nowadays, vegetation can be seen as an additive material to building construction in order to increase multi functionality of building envelope [1].

Green roofs and green facades provide better thermal insulation of buildings and reduce the influence of the effect of urban heat island which causes global warming. The greenery also has a role in air purification and due to increased evapotranspiration, it reduces carbon dioxide emissions. Rainwater runoff is mitigated, especially by green roofs, which prevents the risk of flooding. Those advantages are analysed in the paper, from the environmental point of view, and the results show advantages of the systems compared to conventional built constructions.

There are certain obstacles in implementation and formation of green roofs and green facades, but the fulfilment of the environmental requirements justifies their construction.

\section{GREENING BUILDING ENVELOPE}

The building greenery systems can be placed on the top of the building, at flat and sloping surfaces (green roofs) and on the facades in the forms of facade greening and living wall systems, depending on layers structure.

\section{Green roof concept}

As a part of the layer of the structure, green roof enables the development of vegetation on flat and sloping surfaces up to the inclination of $58^{\circ}$. They can be extensive, with a low and medium amount of greenery, and intensive, requiring structures with a great load-bearing capacity for the development of greater verdure and the formation of roof gardens. The type of low greenery which forms the final layer in extensive green roofs depends on the climatic conditions of the region. Plants are most frequently self-sustained since they use natural conditions (the sun, wind and rainwater) [2]. The layer condition needs to be assessed 2-3 times per year. In case of intensive green roofs, it needs to be maintained (cleaning and watering). Figure 1 shows a standard structure of a green roof [3]

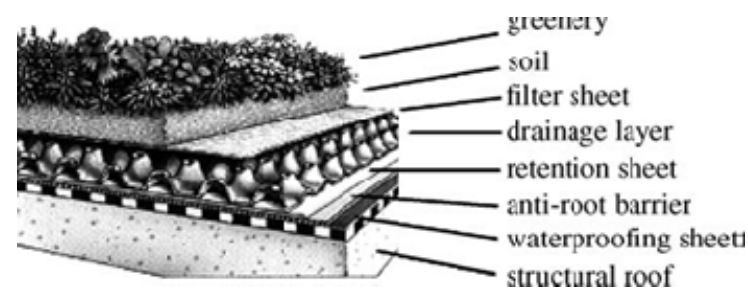

Figure 1. Green roof structure [3] 


\section{Green facade concept}

Green facade or vertical garden is a term which is used to refer to all forms of vegetated wall surfaces [1]. It is the result of greening vertical surfaces with plants which can be rooted into the ground, in the wall material or in panels attached to the facade in order to cover buildings with vegetation (Fig. 2). According to their growing method, vertical gardens are classified into facade greening and living wall systems [4].

The plant choice affects aesthetical and functional aspects of a greened facade. An evergreen plant protects the facade from wind flow and precipitation, which is important for the continental climate or for north oriented facades. A deciduous plant allows the building envelope to change visually and it is more suitable for the mild Mediterranean climate [5].

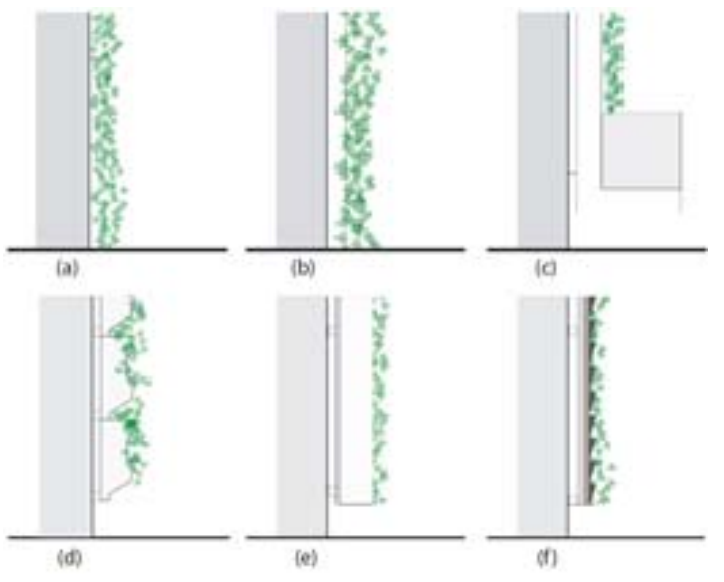

Figure 2. Vertical greening systems: a - direct greening system, $b$-indirect greening system, $c$-indirect greening system combined with planter boxes, $d-L W S$ based on planter boxes, $e-L W S$ based on foam substrate, $f-L W S$ based on felt layers [5]

\section{ECOLOGICAL BENEFITS}

The ecological aspects of integration of vegetation within the building envelope could be researched through their benefits compared to conventional bare facades and roofs. Mitigation of the effect of urban heat island, reduction of rainwater runoff and air quality improvement due to greening the building envelope in urban areas were studied in this paper.

\section{Mitigation of the effect of urban heat island}

The temperature in urban areas rises with the increase of absorbing surfaces which retain the heat they accumulate during the day and emit it during the night into the surroundings, causing the effect of urban heat island. This occurs because the land surface is characterized by high solar absorption and high impermeability, which represents favourable thermal properties for energy storage and heat release [6]. Difference in temperature between the city centre and the suburbs during the summer months may be up to $10^{\circ} \mathrm{C}$, which greatly impacts the health and quality of life of the residents. Greenery may absorb up to $80 \%$ excess heat energy through damp soil and vegetation.

Analyzing the energy performance of green roofs, it can be seen that the benefits of greenery shading are evident. Experimental research conducted on the green roof of the Regional Council of Marche in Italy included the measurements of the solar irradiance above and below the vegetation [7]. The presence of vegetation creates a shadow on the soil, which allows decreasing the incident solar irradiance on the external surface of the roof, hence reducing the temperature and the heat gain through the construction. Significant reduction of solar energy inside the layers of the green roof was measured (up to 90\%). The results are presented in Table 1.

Table 1. Reduction of the daily solar irradiance observed at the green roof of the Regional Council of Marche (Italy) [7]

\begin{tabular}{cccc}
\hline Day & $\begin{array}{c}\text { Solar } \\
\text { energy } \\
{\left[\mathrm{Wh} / \mathrm{m}^{2}\right]}\end{array}$ & $\begin{array}{c}\text { Solar energy } \\
\text { below the } \\
\text { foliage } \\
{\left[\mathrm{Wh} / \mathrm{m}^{2}\right]}\end{array}$ & $\begin{array}{c}\text { Reduction } \\
{[\%]}\end{array}$ \\
\hline 14 May 08 & 6603.33 & 1067.00 & 83.84 \\
\hline 15 June 08 & 8320.25 & 1416.50 & 82.97 \\
\hline 16 July 08 & 8121.75 & 1525.75 & 81.22 \\
\hline 14 Aug 08 & 6982.50 & 952.25 & 86.63 \\
\hline 11 Sep 08 & 5480.58 & 519.33 & 90.52 \\
\hline
\end{tabular}

Since the roof surfaces of the buildings accounts for the $20-24 \%$ of the total urban surfaces, they can be successfully used for reducing the air and surface temperature of urban areas [8].

The ability to reduce the effect of urban heat island due to the presence of vertical greenery systems was researched within the Ayer Rajah Industrial Park in Singapore, using an air temperature prediction model [9]. The internal temperatures, maximum and minimum values, were measured considering two scenarios. In first scenario (A), the glass facade was opaque and in the other (B) was with $100 \%$ greenery coverage. The values shown in Table 2 indicate a reduction in the energy cooling load of $74.29 \%$.

Table 2. Digital simulation for internal temperatures [9]

\begin{tabular}{cccc}
\hline Scenarios & $\begin{array}{c}\text { MRT }\left[{ }^{\circ} \mathrm{C}\right] \\
\text { Minimum }\end{array}$ & $\begin{array}{c}\text { MRT }\left[{ }^{\circ} \mathrm{C}\right] \\
\text { Maximum }\end{array}$ & $\begin{array}{c}\text { Energy } \\
\text { reduction } \\
{[\%]}\end{array}$ \\
\hline $\mathrm{A}$ & 30.28 & 34.39 & - \\
\hline $\mathrm{B}$ & 23.20 & 24.01 & 74.29 \\
\hline
\end{tabular}

This result points to the great thermal benefits of green facades regarding the reduction of the surface temperature of buildings facades in the tropical climate. The reduction for the case in continental climate certainly would be lower, but significant for the densely built areas. 


\section{Reduction of rainwater runoff}

Water circulation is a natural process which plants have a significant role in. Through the transpiration of plants and the evaporation of substrates, the greater portion of the rainwater quickly returns to the water circulation cycle. This leads to the reduction of rainwater runoff and decrease of the sewage system loads by approximately $700 \mathrm{l} / \mathrm{m}^{2}$ of green roof water annually, as well as possible spills and floods. Although numerous factors influence water retention capacity and runoff dynamics, greening the building envelope represents a sustainable approach for the reduction of sewage network dimensions, as well as the number of drains and ducts.

Mentens et al. [10] attempted to answer whether the green roof may be a tool for resolving rainwater runoff problems in urban areas. They conducted a comparative analysis of four roof types for the region of Brussels, Belgium. According to the results shown in Figure 3, non-greened roofs (trad) reach values of annual runoff up to $91 \%$, while the minimum values of $15 \%$ were measured for intensive green roofs. It needs to be stressed that the thickness of substrates for intensive green roofs exceeds $100 \mathrm{~mm}$, and is lower than 100 $\mathrm{mm}$ in the case of extensive ones, which may also be formed on sloping roof surfaces. It can be concluded that intensive green roofs have the greatest retention capacity.

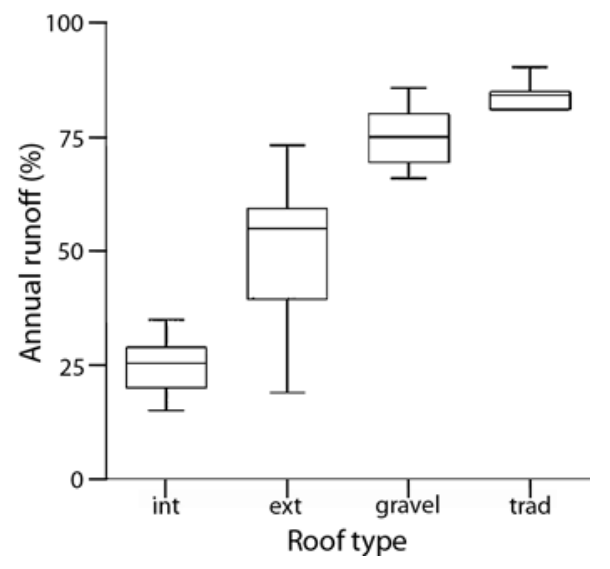

Figure 3. Annual runoff for various roof types as a percentage of the total annual rainfall [10]

From a literature review, it can be found that the volume retention capacity of green roofs is in the range from $40 \%$ to $80 \%$ of the total rainfall volume [7]. However, in specific cases many factors have to be taken into account, regarding the characteristics of construction and roof position, as well as weather conditions [11].

In the case of green roofs, the initial time of runoff is delayed, the peak and rainwater runoff quantity are reduced and the runoff is distributed over a long time period through a relatively slow release [12]. Regarding green facades, the distribution of the runoff takes less time because of its position. More important is the process of evapotranspiration, because by this process the largest amount of rainfall is retained and returned to the atmosphere. Figure 4 shows the mean evapotranspiration of a facade greening system [13]. The values were between 5.4 and $11.3 \mathrm{~mm}$ per day, depending on which floor the planters were located.

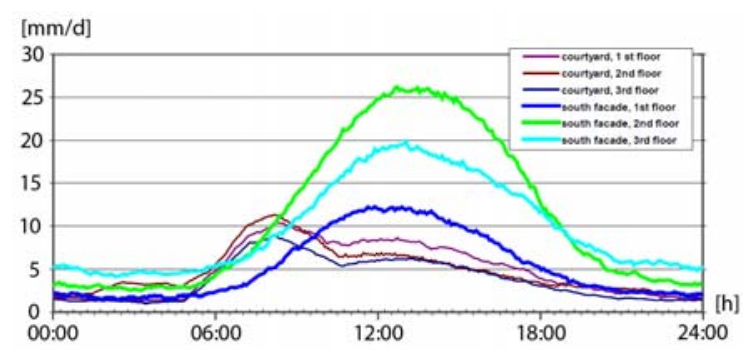

Figure 4. Mean evapotranspiration of the facade greening system and courtyards on first, second and third floor with south orientation [13]

Beside the effect of reduction the rainwater runoff, the process of evapotranspiration has a cooling effect on the building. For the presented study, the mean cooling value is $157 \mathrm{kWh} /$ day [13].

\section{Air quality improvement}

It is a well-known fact that vegetation in urban areas has a favorable impact on the reduction of air pollution, which is saturated with harmful gases, volatile organic compounds, particles and other products of burning fossil fuels and industries that adversely affect human health.

There has been many published studies on the ability of vegetation to improve the air quality, but only few specific to green roofs or green facades [14]. Vegetation can remove pollutants in several ways. Plants take up gaseous pollutants through treir stomates, intercept particular matter with their leaves and they are capable to breaking down certain organic compounds in their plant tissues or in the soil [14]. They also indirectly reduce air pollutants by lowering surface temperatures through evapotranspirational cooling and by providing shade. Considering this, photochemical reactions which form pollutants such as ozone are decreased.

The air quality improvement due to vegetation is mainly related to the uptake of gaseous pollutants and the absorption of fine dust particles. For example, carbon dioxide is used by plants for the photosynthesis process creating oxygen and biomass, and nitrogen and sulfur dioxide are converted into nitrates and sulfates in the plant tissue. The fine dust particles, especially the smaller size fractions (less than $10 \mu \mathrm{m}$ ), are mainly adhered to the outside of the vegetation parts [15]; therefore vegetation is a perfect sink for airborne particles. It is estimated that $2000 \mathrm{~m}^{2}$ of green roofs with grass as a vegatation layer, would remove up to 
$4000 \mathrm{~m}^{2}$ of particulate matter [14]. Figure 5 shows the upper side of a leaf with particulate matter cover.

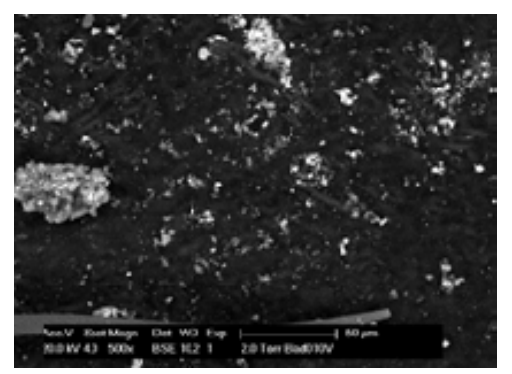

Figure 5. Electron microphotograph of particulate matter on the upper side of a leaf [5]

\section{OPPORTUNITIES AND BARRIERS FOR GREENING BUILDING ENVELOPE}

Greening building envelope is a process which can be done in the stage of design or in the stage of building renovation. Since the need for increasing the greenery is occurred in densely built urban areas, the opportunities and barriers for implementation the vegetation within the buildings refer to existing buildings.

The significance of greening building envelope in urban areas is huge, and ecological benefits are particularly pronounced. Although the improvement of living conditions and healthier environment cannot be expressed only in financial terms, such constructions have a high price [16]. For instance, a $19 \mathrm{~m}^{2}$ of extensive green roof can remove the same quantity of pollutants as a medium sized tree, but the planting costs are approximately $\$ 3059$ and $\$ 400$, respectively [14]. The lack of space causes the establishment of greening systems. Their cost is justified by the durability of construction. The greenery protects building envelope from ultraviolet radiation and the extreme fluctuations in membrane temperature between day and night, which causes the construction failure.

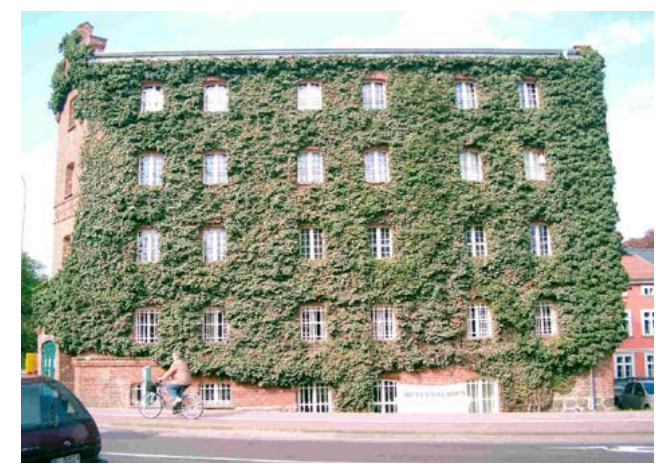

Figure 6. Vertical greening system about 100 years old, Germany [4]

The estimation of life span of a conventional flat roof is 15 - 20 years and a green roof last minimum twice longer [17]. Vertical greening systems may last even longer, but the durability depends on the chosen system and type of greenery. Green facade of a building in Germany, planted with English ivy is about 100 years old (Fig. 6) [4].

The load-bearing capacity of the existing roof or facade structure influences the choice of the type of the greening system to be constructed. The most frequent structures are extensive green roofs and greened facades based on the use of climbers rooted into the ground. Extensive green roof construction mostly does not require additional supports to the structure, because their weight is lower $\left(72.6-169.4 \mathrm{~kg} / \mathrm{m}^{2}\right)$ compared to intensive ones $\left(290-967.7 \mathrm{~kg} / \mathrm{m}^{2}\right)$ [18]. The mentioned green facades have low weight, but the living wall systems require special additional supports and the decisions are made in the design process. The full load must account for the weight of the greening system soaked in rainwater.

The position of the building with respect to other neighboring buildings, as well as its orientation, influences the selection of the vegetation type. Formation of green roofs and green facades on buildings shaded by neighboring structures, as well as at non-favorable oriented locations for vegetation, requires careful choice of various types of plants which are able to survive under such conditions.

Every specific case requires complete analysis starting from the building location, orientation and condition, greening system construction requirements, climatic conditions and finance which is usually the main limiting factor.

\section{CONCLUSION}

Degradation of natural surroundings in urban areas may be reduced by greening building envelope. Considering ecological values which have to be increased in order to improve overall living conditions, some of the benefits of greening systems were analyzed. From presented studies it can be concluded that green roofs and green facades have favorable impact on resolving the crucial problems of urban areas, such as the effect of urban heat island, rainwater runoff and air pollution.

The popularity of greening systems is growing in the context of urban landscaping because of its smaller footprint, aesthetic values and the environmental benefits of construction. As green roofs are widely used, vertical greening systems can be a potential for high buildings in densely built urban centers, because of the large facade surface area in regard to roof area.

Although the starting investments in greening systems are very high, they are justified by the realized quality of the environment in the short run and by the durability of the structure in the long run.

This brief overview of ecological benefits from green roofs and green facades aims to promote them in the region of West Balkans and South East Europe. 


\section{REFERENCES}

[1] M. Ottele, K. Perini, A. L. A. Fraaij, E. M. Haas, R. Raiteri: "Comparative life cycle analysis for green facades and living wall systems", Energy and Buildings, Vol. 43, 2011, pp. 341 9- 3429., http://dx.doi.org/10.1016/j.enbuild.2011.09.010

[2] T. Liptan, E. Strecker: "EcoRoofs (Greeroofs) - A more Sustainable Infrastructure", Portland Oregon, USA: Bureau of Environmental Services, 2003.

[3] R. M. Lazzarin, F. Castellotti, F. Busato: "Experimental measurements and numerical modelling of a green roof", Energy and Buildings, Vol. 37, 2005, pp. 1260 - 1267. http://dx.doi.org/10.1016/j.enbuild.2005.02.001

[4] M. Kohler: "Green facades - a view back and some visions”, Urban Ecosystems, Vol. 11, 2008, pp. 423 436. http://dx.doi.org/10.1007/s11252-008-0063-x

[5] K. Perini, M. Ottele, E. M. Haas, R. Raiteri: “Greening the building envelope, facade greening and living wall systems”, Open Journal of Ecology, Vol. 1, 2011, pp. 18. http://dx.doi.org/10.4236/oje.2011.11001

[6] M. Zinzi, S. Agnoli: "Cool and green roofs. An energy and comfort comparison between passive cooling and mitigation urban heat island techniques for residential buildings in the Mediterranean region", Energy and Buildings, Vol. 55, 2012, pp. 66 - 76. http://dx.doi.org/10.1016/j.enbuild.2011.09.024

[7] R. Fioretti, A. Palla, L. G. Lanza, P. Principi: “Green roof energy and water related performance in the Mediterranean climate”, Building and Environment, Vol. 45, 2010, pp. $1890 \quad-\quad 1904$. http://dx.doi.org/10.1016/j.buildenv.2010.03.001

[8] H. Akbari, S. L. Rose, H. Taha: “Analyzing the land cover of an urban environment using high-resolution orthophotos”, Landscape and Urban Planning, Vol. 63, 2003, pp. 1-14. http://dx.doi.org/10.1016/S01692046(02)00165-2

[9] N. H. Wong, A. Y. K. Tan, P. Y. Tan, N. C. Wong: "Energy simulation of vertical greenery systems", Energy and Buildings, Vol. 41, 2009, pp. 1401 - 1408. http://dx.doi.org/10.1016/j.enbuild.2009.08.010

[10] J. Mentens, D. Raes, M. Hermy: "Green roofs as a tool for solving the rainwater runoff problem in the urbanized 21st century?”, Landscape and Urban Planning, Vol. 77, 2006, $\quad$ pp. 217226. http://dx.doi.org/10.1016/j.landurbplan.2005.02.010

[11] M. Stamenkovic, D. Gavrilovic: "Green roofs as a tool for managing rainwater runoff”, Proceedings of International Conference - Innovation as a Function of Engineering Development, Nis, Serbia, 2011, pp. 352 330.

[12] J. S. Berndtsson: "Green roof performance towards management of runoff water quantity and quality: A review”, Ecological Engineering, Vol. 36, 2010, pp. 351 - 360. http://dx.doi.org/10.1016/j.ecoleng.2009.12.014

[13] M. Schmidt: "Energy and water, a decentralized approach to an integrated sustainable urban development”, Proceedings of the International Conference - RIO 6 - World Climate and Energy Event, Rio de Janeiro, Brazil,, pp. 53 - 59.

[14] D. B. Rowe: "Green roofs as a means of pollution abatement”, Environmental Pollution, Vol. 159, 2011, pp. 21002110 http://dx.doi.org/10.1016/j.envpol.2010.10.029 PMid:21074914

[15] M. Ottele, H. Van Bohemen, A. L. A. Fraaij: "Quantifyng the deposition of particulate matter on climber vegetation on living walls", Ecological Engineering, Vol. 36, 2010, pp. 154 - 162. http://dx.doi.org/10.1016/j.ecoleng.2009.02.007

[16] C. Y. Jim: "Sustainable urban greening strategies for compact cities in developing and developed economies", Urban Ecosystems, Vol. 15, 2012, pp. 1 - 21.

[17] L. van Wyk: "Green Roofs. The Green Building Handbook”, 2010. Available at: http://researchspace.csir.co.za/dspace/bitstream/10204/4 458/1/Van\%20Wyk1_2010.pdf [accessed 23.10.2010].

[18] S. W. Peck, C. Callaghan, M. E. Kuhn, B. Bass: "Greenbacks from green roofs: Forging a new industry in Canada”, Canada Mortgage and Housing Corporation, 1999, Ottawa, Canada.

\section{BIOGRAPHY}

Dragan Gavlilović was born in Leskovac, Serbia, in 1948.

He received the diploma from the University of Niš, Faculty of Civil Engineering, department of architecture. After graduation he was employed in the construction operative, where he gained

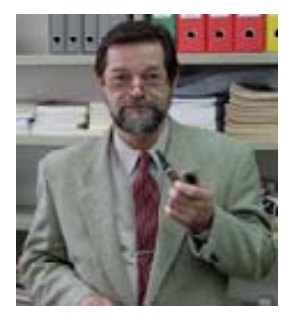

valuable experience in the construction of residential buildings. He entered post graduate studies at the University of Niš, and received a master's degree in the field of passive solar architecture. In 1980, he began working at the Faculty of Civil Engineering as a teaching assistant. He received the Ph.D. degree in the field of bioclimatic architecture, in 1997.

He is currently working as a professor at the Faculty of Technical Sciences in Kosovska Mitrovica, University of Priština. 


\section{EKOLOŠKE PREDNOSTI OZELENJAVANJA FASADA U ZGRADARSTVU}

\section{Dragan Gavrilović, Marija Stamenković}

Rezime: Ekstenzivni urbani razvoj donosi mnoge nepovoljne uticaje koji se ogledaju u degradaciji kvaliteta života $i$ zdravlja stanovnika. Neki od ovih uticaja odnose se i na širenje nepropustljivih površina (od betona, asfalta, stakla, itd) u gradskim jezgrima. Sa aspekta zaštite životne sredine, negativni efekti urbanizacije uključuju povećanu temperaturu $i$ efekat „urbanog toplotnog ostrva“, koji doprinosi globalnom zagrevanju, aerozagagađenju, opasnosti od poplava i smanjenju prostora za floru i faunu. Jedan od načina za ublažavanje ovih efekata je ozelenjavanje fasada zgrada.

Rad se odnosi na ekološke prednosti koje se mogu ostvariti pokrivanjem površina zgrada zelenilom. Uporedna analiza zgrada prekrivenih zelenilom $i$ onih sa konvencionalnim materijalima ostvarena je na osnovu podataka iz određenih inostranih studija. Rezultati prikazani u ovom radu ukazuju na značajno poboljšanje životnih uslova u zgradama sa zelenim pokrivačem i potvrđuju da integracija vegetacije predstavlja održivi pristup projektovanju u zgradarstvu, kako za nove, tako i za postojeće objekte.

Ključne reči: zeleni krovovi, zelene fasade facades, urbano okruženje, održivo projektovanje 